\title{
Cooking Energy Nexus in the Policy on Rural-Urban Indices and Climate Change Mitigation in Nigeria
}

\author{
Taiwo A. Olaiya, $\mathrm{PhD}$ \\ Department of Public Administration, Obafemi Awolowo University, Ile-Ife
}

\begin{abstract}
Despite the preponderance of solid fuels as a major source of cooking energy in Africa, mainstreaming their contributions to rural-urban inequalities and climate change in scholarly debates and policy advocacy appears incommensurate. This article engages the discursive reconstruction of the interdisciplinary debate about how energy choices shape poverty incidences and climate change. Emphasis is on the conceptualisation of rural-urban inequalities and climate change in relation to cooking energy sources. How may policy advocacy for cooking energy choices in Africa induce poverty alleviation and climate change? What lessons are discernible from national policies on cooking energy and why the tendency for more alternative cooking energy at the urban centres than the rural areas? These questions are analysed mainly from a systematic review of policy literature and quantitative data sourced from key rural and urban informants in the south-western region of Nigeria, the most populous state in Sub-Saharan Africa. The theoretical foundation is hinged on Rational Choice Theory to explain how individual cooking energy choices can interact to generate often surprising aggregate outcome on poverty incidences and climate change. Evidence mainly reveals that cooking energy choices significantly shape rural-urban indices and climate change mitigation. Implications for climate change and development are also discussed.
\end{abstract}

Keywords: climate change mitigation, urban-rural indices, rational choice, alternative cooking energy, Nigeria, Africa

DOI: $10.7176 / \mathrm{JESD} / 11-8-10$

Publication date: April $30^{\text {th }} 2020$

\section{Introduction}

Southwest Nigeria is located at the fringe of the Atlantic Ocean. It is an Amazon forest region that is made famous due to her dense forest, wild rain and tropical fruits. Climate change has had unbridled effects on the region, which is often described as a natural green zone. Climate change in the Southwest, Nigeria, could be practically explained in terms of drought, inclement weather condition, ocean surge, inundated rainfalls, heat waves and communicable diseases. This paper attempts to empirically examine climate change in relations to alternative cooking energy available to women in urban and rural area in the Southwest, Nigeria. In this article, climate change is considered as anthropogenic in underlying circumstances, especially as it concerns the usages of non-renewable energy. The article explored the universality of the consequences of human activities on earth by looking beyond the discourses of climate change hinged around the pollutions arising from industrialisation in the developed and developing nations. Instead, the paper examined the appropriations of micro human activities as they accentuate to explain the anthropogenic contributions of man in non-industrialised local communities. As Sachs (2015) and Olaiya, Ayinde, Alayinde and Akinwole (2016) have suggested for further studies, the paper focussed on the non-industrialised region of sub-Saharan Africa in a unique comparative analysis of the activities of women in the urban and rural areas. Folami and Folami (2013) argued that the causal factors relating to climate change are traceable, mainly, to the industrialised nations, even though its consequences are felt more in the non-industrialised nations such as Nigeria. A critical scientific claim, Purdy (2010), established that carbon dioxide gets evenly dispersed in the atmosphere within a year release. As the author pointed out: while a fossil fuel user, say a transatlantic traveller, enjoys the full benefit of his voyage whether in flight or navigations in water, he spreads the harm of carbon emission on over seven billions other inhabitants of the Earth. Such an unfair scenario, according to Purdy (2010:1132), "is a ratio of benefit to harm all but certain to induce overindulgence". In non-industrialised nations like Nigeria, climate change could is attributable to over-dependency on fossil fuel and woods. For example, many households in Nigeria depend on wood, gas, kerosene stoves, solar energy, electric stove and other sources of energy for cooking (Oyedepo, 2013). Most of the traditional sources of cooking energy used by the majority of Nigerians are climate change prone.

A fundamental socio-political and economic issue in the annals of global developmental agenda is access to clean energy. As Amar (2012) rightly pointed out, the place, quantity and quality of energy consumption cannot be overemphasised because the "access to energy is a fundamental issue in the challenge of development". Shankar and Sharma (2012) argued that access to clean and affordable energy by all and sundry is nothing short of a "fundamental human right" and "an indispensable tool for the attainment of a respectable quality of life". Despite decades of research and finances channelled towards the production of affordable energy in the world, access to modern energy sources still remains a nightmare in the global south (Edomah, 2018; Samadiafshar \& Ghorbani, 2018; Griffiths, 2019). Apart from the slow transition from fossil fuel usage across the globe, fossil fuel accounts 
for over three-quarter of the entire global energy consumption for the past six decades (Griffiths, 2019). Of the somewhat 7.5 billion people in the world, more than one-fifth still lacks access to electricity and over two-third still count inevitably on solid energy cooking sources (Pachauri, Rao, Nagai, \& Riahi, 2012; Situmbeko, 2018). Sub-Saharan Africa remains the worst hit in terms of access to modern energy sources with over $70 \%$ living without electricity and over 90\% still relying exclusively on firewood (Pachauri et al., 2012; Situmbeko, 2018; Awodumi \& Adewuyi, 2019). As Awodumi and Adewuyi (2019) argued, the entire gamut of the states in subSaharan Africa uses non-renewable sources of energy. In the rural area, several surveys revealed that a significant source of cooking energy is firewood, followed distantly by kerosene (Olaiya et al., 2016). To source firewood, users fell trees at random and by various means: some by simply cutting down and a good number by burning down the trees. As Sachs (2015) has pointed out, the cutting down of trees on its own, let alone burning the trees to produce cooking firewood, is climate-damaging. As Emodi and Boo (2015) pointed out, over 350,000 hectares of forest land suffer annual acute deforestation not only due to felling of trees and its attendant consequences on climate change but also for lack of reforestation commensurate plans.

Available statistics revealed that solid fuel like raw biomass and firewood led to the death of over 2.2 million people in 2005 alone from mainly sub-Saharan Africa and South East Asia (Pachauri et al., 2012). In Nigeria, only about half of the population, two-thirds of which are resident in urban centres, have access to electricity (Arowolo, Blechinger, Cader \& Perez, 2019). The National Energy Policy (2003) and the Sustainable Energy for All: Action Agenda (2016) in Nigeria recognised the availability of various types of renewable energy and proposed urgent measures to drive the policy to a logical conclusion. Nevertheless, a vast majority of residents at the rural centres, excluding the alternative biofuel users at the urban areas, use solid fuels such as firewood, kerosene and diesel (Gujba, Mulugetta \& Azapagic, 2015; Sa'ad \& Bugaje, 2016; Ajayi \& Ajayi, 2019; Edomah, 2019). As Gielen, Boshell, Saygin, Bazilian, Wagner and Gorini (2019) pointed out, the attendant consequences of overconcentration on non-renewable energy on the overall economic growth cannot be overemphasised. Also, smoke emanating from firewood used for cooking is the third highest killer of women and children in Nigeria (Amar, 2012). There is no gainsaying that the excessive usage of firewood for cooking constitutes a significant pollution hazard in households. An online magazine, Premium Times, published that the over 93,300 Nigerians died annually due to inhalations and complications from smoke emanating from conventional firewood and kerosene stoves. Also, an estimated 72 per cent of Nigeria's population depend solely on firewood for cooking (Premium Times, 2013). The abundance of fossil fuel sources in Nigeria is mainly responsible for the increased utilisation (Oyedepo, 2013; Emodi \& Boo, 2015). According to Oyedepo (2013), Nigerians source about 92\% cooking energy from firewood and biomass (petroleum) fuel. Of all, the households consumed over half of the total energy usage in Nigeria (Oyedepo, 2013).

Nigeria occupies a pride of place in the energy discourse of (sub-Sahara) Africa. Situmbeko (2018) argued that more than half of the world's electricity users live in sub-Saharan Africa. As the most populated African state, and the one with highest oil and gas reserves, and oil revenue, Nigeria's consumption of energy for household, industries and transportation is commensurably gigantic and above all else (Ejiogu, 2012; Sa'ad \& Isah, 2016). By that same token, Nigeria has one of the highest records of deaths by smoke-related causes in the world. A reputable international organisation, International Center for Energy, Environment and Development (ICEED), submitted that the more than 30 million households comprising about 100 million people in Nigeria depend entirely on firewood for daily cooking and heat. This condition prevails mostly in rural communities much more than the urban centres. A national tabloid in Nigeria quoted ICEED that nearly two-third of urban households in Nigeria utilise firewood as the primary source of cooking energy (The Nation, 2014). Emodi and Boo (2015) pointed out that there is a general prevalence of energy poverty in Nigeria. According to the authors, energy poverty specifically denotes lack of access to clean energy such as electricity and gas, which are generally unavailable for most households cooking in Nigeria.

From the submissions of most scholarly and public opinion writers, there appears little or no departure from the notion that Nigeria is a profound patriarchy society (Folami \& Olaiya, 2016; Igbelina-Igbokwe, 2013; Makama, 2013; Aina, 1998). According to Dogo (2014), the situation is so distinguished as evidenced by practical and generally accepted allocation of gendered duty/relation in line with, and propagation of, patriarchy. As IgbelinaIgbokwe (2013) argued, practical patriarchy defines the core of social and conjugal relation between Nigeria men and women in a typical representation of most African societies. As a patriarchy society, cooking is traditionally ascribed to women in the Southwest, Nigeria (Aina, 1998). The gendered allocation of cooking chores to women explains the reason why this study focuses on sources of cooking energy available to women in the Southwest, Nigeria. The cooking energy used by women is primarily determined by the availability of alternatives sources of energy. While the provision of alternative sources of cooking energy appears to be limited to urban women, rural women depend solely on wood for cooking. The article, therefore, examines the determinants of the source of cooking energy for both rural and urban women. It also examines the relationship between climate change mitigation and the availability of sources of cooking energy for women.

This article is further divided into subsections. First, the article discussed the appropriateness of rational 
choice theory for explaining the issues surrounding choices that individual makes as sources of energy and the cumulative effects on climate change. Second, it examined women, source of energy and rational choice. Third, we discussed the research method, comprising the design, data sources and selection of participants for the research. Fourth, the results of the analysis of the data collected were present. Finally, the conclusions emanating from the discussions of findings are presented in conjunction with their positions within the existing body of knowledge. The policy implications of the conclusions also featured in the last subsection.

\section{Theoretical expositions}

The section discusses the adopted theoretical framework and its appropriateness for explaining the cooking energy choices the rural and urban women made, with or without available alternative sources. The debate about how actions embarked upon by rational individual decision-makers often interact to generate surprising aggregate outcomes has made Rational Choice Theory (RCT), a popular research methodology in climate change. The central idea embedded in the theory is that rational socio-economic choices at the individual level about cooking energy could metamorphose into a mass outcome that induces or exacerbate climate change. The section also discusses the concept of sustainable development in relation to climate change, most notably as induced by cooking energy. The idea here is to raise a profound discourse from the literature on sustainable development and cooking energy.

Furthermore, the nature and effects of human activities in the Anthropocene on climate change are also discussed in the section. Here, the world is recognised as a global village in which the anthropogenic action taken in one part ricochets in numerous other places whether far or near. In other words, the discourse here is to examine whether the choice of cooking energy in, say, rural Africa areas is capable of snowball effect in Europe. Lastly, the section explores the phenomenon of the ever-expanding world population to explain how the far, fast and vast the individual choices could accelerate climate change all over the world.

\section{Rational Choice, Women and Source of Energy}

Rational Choice Theory (RCT) is arguably an essential analytical tool for the explanations on women's source of and choices for cooking energy. It is a more rational decision to change to green energy that faces the consequences of climate change. Apart from economic rationality identifies with Rational Choice Theory from the inception. The theory has a strong standpoint in Bentham's utilitarian philosophy of the $18^{\text {th }}$ century. Max Weber (1920), for example, built an influential typology of action around traditional, emotional and value-oriented action. Another sociologist, Talcott Parsons (1937) takes the argument further by incorporating empirical explanation of human action based on alternative rational choice. Similarly, the social anthropologists Bronislaw's preposition on the principles of reciprocity and social obligation fitted into the arguments on rational choice.

Malinowski (1922) and Marcel Mauss (1925) examined how the social exchange was embedded in human action. Rational choice theory in sociology begins with the work of Homans (1961). Homans (1961) positions $\mathrm{RCT}$ as an action recognised by traditional or habitual action, emotional or affectual action, and various forms of value-oriented action. Scott (2000) highlights some propositions on rational choice theory. According to Scott (2000), Rational choice adopts a methodological individualist position and attempts to explain all social phenomena in terms of the rational calculations made by self-interested individuals. The theory sees social interaction as social exchange modelled on economic action. People are motivated by the rewards and costs of actions and by the profits that they can make.

Some rational choice theorists have seen rationality as a result of psychological conditioning. Others have adopted the position that it is merely necessary to assume that individuals act as if they were entirely rational. Scott (2000) further states that the problem of collective action poses great difficulties for rational choice theory, which cannot explain why individuals join many kinds of groups and associations. The problem of social norms, the other aspect of the Hobbesian problem of order, also poses difficulties. Rational choice theory cannot explain the origins of social norms, especially those of altruism, reciprocity, and trust. The problem of social structure is a feature of methodological individualism, rather than a rational choice theory per se, but it creates difficulties for the theories considered. Solutions to this problem have been in terms of the unintended consequences of individual action. Ostrom (1998) and Ostrom (1990) present a different view on RCT which focuses on how individuals achieve results that are "better than rational" by building conditions where reciprocity, reputation, and trust can help to overcome the strong temptations of short-run self-interest.

In this study, some conjectures are explored as to how individual action often lead to a surprising cumulative outcome. We start with the observation that women from both rural and urban areas are observed as individual players whose respective action combines to bring about hazardous clime change, as predicted in rational choice theory. Because access to cooking energy is limited by technological availability, these women are left with little cooking energy choices other than the largely available fossil fuel and firewood. Although women in the urban areas enjoy government patronage in terms of encouraging people to use bio-fuel and other green energy, lack of supply of these crucial alternative energy choices hardly allows the women in the cities to rely solely on them. Women in the rural area are solely dependent on firewood for cooking. In both rural and urban centres, woods are 
axed down indiscriminately. Apart from the fact that the chopping down of wood contributes to the desertification of hitherto known forest region in Nigeria, the smokes from these individual sources generate carbon dioxide $\mathrm{CO}_{\mathrm{C}}$, which are trapped in the atmosphere as a greenhouse gas, among others. In effect, the cumulative action of the women from both rural and urban areas is capable of leading to 'concentration' or 'abundance' of greenhouse gas, which is causes climate change (US EPA, 2016).

\section{Method and Materials}

The study was carried out in the Southwest, Nigeria. Southwest, Nigeria comprises six states such as Ekiti, Lagos, Ogun, Ondo, Osun and Oyo. The region parades numerous natural resource such as cocoa, cassava, timber, bitumen, natural gas, oil palm and crude oil. Farming and fishing are the principal occupations of the inhabitants of the southwest, Nigeria. The inhabitants of the region are also into exportation of agricultural products like cocoa, vegetables, cassava, and fruits. The Atlantic Ocean bounds the region in the South, middle-belt region in the North, Benin Republic in the West and Eastern Region. The population of the six states comprises the region was fifty million (population atlas, 2018). Lagos State is the most cosmopolitan among the states in the region. Its population is over twenty million. There are fewer rural settlements in Lagos, Oyo and Ogun States while Ekiti, Osun and Ondo States could account for a larger rural settlement. In the southwest, states like Lagos, Ogun and Ondo are located on coastal lines while Ekiti, Osun and Oyo are hinterland States.

Three out of six states in the Southwest, Nigeria were selected as the study location. Systematic sampling method was used to select the States, including Lagos, Ondo and Osun. In a fair combination of the urban and rural targets, the study was carried out in one rural and one urban setting in each selected state: Lagos (Ikeja and Ito-Ikin); Ondo (Akure and Awo); and Osun (Ile-Ife and Yekemi)

Fig 1: Southwest Nigeria Map

\section{Participants}

Household surveys collected by the National Population census in 2006 were sourced from each of the states selected for the study (see 2006 Population Census). The household survey was also utilised by various organisations including the Faribs Consult in a study sponsored by the UNhabitat on "Good Urban Governance in Nigeria'. Random sampling technique, with a five-scale interval, was used to select the participants. Three hundred and fifty-five participants were selected in the six locations. The house survey consists of the name, address, and location of selected participants. Nine participants refused to participate in the study. The reason given had to do with patriarchy, which limits the women's authority in the family. Eight out of the nine participants who refused to participate in the study were from rural areas such as Ito-Ikin, Awo and Yekemi. The efforts of the researchers to persuade the husbands of the participants to allow their wives to be involved in the study proved abortive. Information regarding the participants was immediately removed from the database designed for the study. Two hundred and fifteen participants fully participated in the study. The number represents $76.4 \%$ of the total number of expected participants. The followings were the distribution of the participants in the study:

Table 1: Distribution of Participants

\begin{tabular}{|l|l|l|l|l|l|l|l|l|}
\hline Location & \multicolumn{2}{|l|}{ Lagos } & \multicolumn{2}{l|}{ Ondo } & \multicolumn{2}{l|}{ Osun } & \multicolumn{2}{l|}{ Total } \\
\hline & No & $\%$ & No & $\%$ & No & $\%$ & No & $\%$ \\
\hline Urban Women & 55 & & 25 & & 26 & & 106 & \\
\hline Rural Women & 23 & & 45 & & 41 & & 109 & \\
\hline Total & 78 & & 70 & & 67 & & 215 & \\
\hline
\end{tabular}

Source: Fieldwork 2019

Legend:

Urban $=$ Ikeja, Akure, Ile-Ife

Rural $=$ Ito-Ikin, Awo; Yekemi

\section{Data Collection}

The study administered structured questionnaires among two hundred and fifteen participants. It contains closeand open-ended questions. The data were collected for over a period of three months. The researcher collected data mostly on Saturdays and Sundays because these periods are work-free days when everybody was expected to be around. The questionnaires administration took place between $10 \mathrm{am}$ and $4 \mathrm{pm}$. The researchers ensured that the participants filled the consent form and information sheet that contains the purposes of the study, rights of the participants, duties of the researcher, names and institutional affiliations of researchers were stated before the beginning of the administration of questionnaires. Though the household survey collected from the National Population Census Office contains the name and addresses of the participants, the researcher deleted such vital information from the administered questionnaires in order to protect the participants. 
Analysis of Data

Data collected were analysed for both descriptive and inferential statistics. Using Chi-square analysis for the categorical variables, the hypotheses were tested. Two hypotheses were tested in this study: (1) there is a significant relationship between climate change and the choice of cooking energy by women; and (2) there is a strong relationship between government policy and climate change mitigation among rural and urban women. Inferences and descriptive narratives were developed from close-ended questions.

\section{Results}

The results of the study, as presented in this section, sequentially discussed climate change awareness, causes of climate change, determinants of cooking energy and reasons for the choice of cooking energy.

Table 2: Climate Change Awareness

\begin{tabular}{|l|l|l|l|l|l|l|}
\hline Awareness & \multicolumn{2}{|l|}{ Urban Women } & \multicolumn{2}{l|}{ Rural Women } & \multicolumn{2}{l|}{ Total } \\
\hline & $\mathrm{N} 0$ & $\%$ & $\mathrm{~N} 0$ & $\%$ & N0 & $\%$ \\
\hline Yes & 89 & 84 & 77 & 70.6 & 166 & 77.3 \\
\hline No & 06 & 5.7 & 11 & 10.1 & 17 & 7.9 \\
\hline I don't Know & 11 & 10.3 & 21 & 19.3 & 32 & 14.8 \\
\hline Total & 106 & 100 & 109 & 100 & 215 & 100 \\
\hline
\end{tabular}

Source: Fieldwork 2019

Awareness of climate change among women in both rural and urban areas selected for this study revealed that 166 out of 215 participants had adequate knowledge about climate change. The participants with "I don't know" response were 32 (14.8). It was not surprising that $11(10.1 \%)$ of the participants in the rural area displayed ignorance about climate change. Also, $21(19 \%)$ of the participants in the rural area failed to give responses to a question on awareness of climate change. It is essential to note that $89(84 \%)$ of women in urban showed that they knew about climate change. Moreover, awareness about climate change has improved tremendously among rural women as revealed by the responses of 77 (70.6\%) participants.

Table 3: Causes of Climate Change

\begin{tabular}{|l|l|l|l|l|l|l|}
\hline Causes & \multicolumn{2}{l|}{ Urban Women } & \multicolumn{2}{l|}{ Rural Women } & \multicolumn{2}{l|}{ Total } \\
\hline & $\mathrm{N} 0$ & $\%$ & $\mathrm{~N} 0$ & $\%$ & $\mathrm{~N} 0$ & $\%$ \\
\hline Deforestation & 31 & 29.2 & 42 & 38.5 & 73 & 34 \\
\hline Oil exploration and exploitation & 21 & 19.8 & 47 & 43.1 & 68 & 31.6 \\
\hline Carbon emission & 47 & 44.4 & 16 & 14.7 & 63 & 29.3 \\
\hline Others & 7 & 6.6 & 4 & 3.7 & 11 & 5.1 \\
\hline Total & 106 & 100 & 109 & 100 & 215 & 100 \\
\hline
\end{tabular}

Source: Fieldwork 2019

Awareness about climate change improved the participants' knowledge about the causes of climate change. More than two-thirds of the participants (73\%) answered that deforestation is liable to cause climate change. A sizable number of participants, $68(31.6 \%)$ of women participants in both rural and urban areas, responded that oil exploration and exploitation is a critical factor in the causes of climate change. Furthermore, some of the participants, 63 (29.3), attributed fossil-fuel emissions as a significant cause of climate change. Finally, a small percentage of the participants, $11(5.1 \%)$, attributed "other" causes of climate change mentioned by women participants in both rural and urban areas as emanating from least-mentioned sources such as war and gas flaring.

Table 4: Effects of Climate Change

\begin{tabular}{|l|l|l|l|l|l|l|}
\hline Effects & \multicolumn{2}{l|}{ Urban Women } & \multicolumn{2}{l|}{ Rural Women } & \multicolumn{2}{l|}{ Total } \\
\hline & $\mathrm{N} 0$ & $\%$ & $\mathrm{~N} 0$ & $\%$ & $\mathrm{~N} 0$ & $\%$ \\
\hline Heat & 15 & 14.2 & 11 & 10.1 & 26 & 12.1 \\
\hline Inundated Rainfalls & 21 & 19.8 & 10 & 9.2 & 31 & 14.4 \\
\hline Diseases & 25 & 23.6 & 13 & 11.9 & 38 & 17.7 \\
\hline Desertification & 11 & 10.4 & 14 & 12.8 & 25 & 11.6 \\
\hline Drought & 15 & 14.2 & 21 & 19.3 & 36 & 16.7 \\
\hline Agricultural Yields & 5 & 4.7 & 23 & 21.1 & 28 & 13.1 \\
\hline Season Planning & 14 & 13.2 & 17 & 15.6 & 31 & 14.4 \\
\hline Total & 106 & 100 & 109 & 100 & 215 & 100 \\
\hline
\end{tabular}

Source: Fieldwork 2019

The result of the study indicates that climate change has had effects on the inhabitants of Southwest Nigeria. The highest proportion of the participants in both rural and urban areas, 38(17.1\%), responded that the effects of climate change are more pronounced in the outbreak of diseases due to exposure to various forms of emissions at close range. Furthermore, the participants responded, at varying degrees, that can lead to drought $(36,16.7 \%)$; inundated rainfalls $(31,14.4 \%)$; inability to plan for the season $(31,14.4 \%)$; low agricultural yield $(28,13.1 \%)$; 
excessive heat $(26,12.1 \%)$ and desertification $(25,11.6 \%)$. To be more specific, the participants from the rural area identified low agricultural yields $(23,21.1 \%)$ and inability to plan for the agricultural season $(17,15.6 \%)$ while participants from the urban women, $25(23.6 \%), 21(19.8 \%), 15(14.2 \%)$ and $15(14.2 \%)$ respectively indicated diseases, indicated rainfalls, drought and excessive heat as the effects of climate change.

Table 5: Sources of Cooking Energy

\begin{tabular}{|l|l|l|l|l|l|l|}
\hline Sources & Urban Women & \multicolumn{2}{l|}{ Rural Women } & \multicolumn{2}{l|}{ Total } \\
\hline & N0 & $\%$ & N0 & $\%$ & N0 & $\%$ \\
\hline Fossil Fuel & 57 & 53.8 & 23 & 21.1 & 80 & 37.2 \\
\hline Wood & 11 & 10.4 & 84 & 77.1 & 95 & 44.2 \\
\hline Solar & 34 & 32.1 & - & - & 34 & 15.8 \\
\hline Electricity & 4 & 3.7 & 2 & 1.8 & 6 & 2.8 \\
\hline Total & 106 & 100 & 109 & 100 & 215 & 100 \\
\hline
\end{tabular}

Source: Fieldwork 2019

Concerning the sources of cooking energy of the participants, results indicated that non-renewable energy sources predominate with renewable cooking energy as the alternative sources in the rural and urban areas. The participants identified Wood $(95,44.2 \%)$ as the highest source of cooking energy by women living in both rural and urban areas; this includes sawdusts, felled trees, chopped wood from sawmills and felling machines and other wood sources. Also, fewer participants, 80(37.2), jointly fingered fossil fuel such as oil, kerosene and coal as the source of cooking energy. Participants from the urban area identified solar, 34(15.8\%), as the coking energy source while their rural counterpart did not give their responses to that effect. Electricity recorded low responses among both urban 4(3,7\%) and rural 1.8\%(2) women.

Table 6: Determinants of Cooking Energy Choice

\begin{tabular}{|l|l|l|l|l|l|l|}
\hline Determinants & Urban Women & \multicolumn{2}{l|}{ Rural Women } & \multicolumn{2}{l|}{ Total } \\
\hline & $\mathrm{N} 0$ & $\%$ & $\mathrm{~N} 0$ & $\%$ & $\mathrm{~N} 0$ & $\%$ \\
\hline Availability & 11 & 10.4 & 11 & 10.1 & 22 & 10 \\
\hline Alternative & 41 & 38.6 & 50 & 45.9 & 91 & 43 \\
\hline Cost & 37 & 35.5 & 39 & 35.8 & 75 & 35 \\
\hline Necessity & 9 & 8.5 & 6 & 5.5 & 15 & 7 \\
\hline Government Policy & 8 & 17 & 3 & 2.7 & 11 & 5 \\
\hline Total & 106 & 100 & 109 & 100 & 215 & 100 \\
\hline
\end{tabular}

Source: Fieldwork 2019

The result on the determinant of cooking energy choices appears to lean more alternative sources to the readily available ones. The participants indicated the determinants of the choice of cooking energy as determined by what is available $(22,10 \%)$; alternative source of energy available (91, 43\%); cost $(75,35 \%)$; necessity $(15,7 \%)$; and government policy $(11,5 \%)$. However, the respondents in both rural and urban area had equal responses to availability $(11,10 \%)$, which implies that women used whatever source of cooking available. Also, participants from the rural area $(50,45 \%)$ identified that the available source of cooking energy available to them are mostly from non-renewable sources such as wood and coal. Finally, some participants from the rural area identified the cost of available cooking energy $(39,35.8)$ as a significant factor in determining the choice of cooking energy.

Table 7: Alternative Choice of Cooking Energy

\begin{tabular}{|l|l|l|l|l|l|l|}
\hline Alternatives & Urban Women & \multicolumn{2}{l|}{ Rural Women } & \multicolumn{2}{l|}{ Total } \\
\hline & $\mathrm{N} 0$ & $\%$ & $\mathrm{~N} 0$ & $\%$ & $\mathrm{~N} 0$ & $\%$ \\
\hline Bio-fuel & 40 & 37.7 & - & - & 40 & 18.6 \\
\hline Electricity & 23 & 21.7 & 12 & 11 & 35 & 16.3 \\
\hline Solar & 43 & 40.6 & - & - & 43 & 20 \\
\hline I don't know & - & - & 97 & 99 & 97 & 45.1 \\
\hline Total & 106 & 100 & 109 & 100 & 215 & 100 \\
\hline
\end{tabular}

Source: Fieldwork 2019

The alternative choice of cooking energy available to the participants were biofuel $40(18.6 \%)$; electricity $35(16.3 \%)$; and solar 43(20\%). Urban participants indicated access to an alternative choice of cooking energy such as bio-fuel 40(37.7\%), electricity $23(21.7 \%)$, solar 43(40.6\%) more than rural women. For the rural, electricity $12(11 \%)$ is the only alternative source identified, while almost all the 109 participants from the area $(97,99 \%)$ participants indicated "I don't know" as the prevailing response. 
Table 8: Reasons for Alternative Choice to Cooking Energy

\begin{tabular}{|l|l|l|l|l|l|l|}
\hline Reasons & \multicolumn{2}{l|}{ Urban Women } & \multicolumn{2}{l|}{ Rural Women } & \multicolumn{2}{l|}{ Total } \\
\hline & $\mathrm{N} 0$ & $\%$ & $\mathrm{~N} 0$ & $\%$ & $\mathrm{~N} 0$ & $\%$ \\
\hline Climate Change & 63 & 59.4 & 40 & 36.7 & 103 & 47 \\
\hline Government Policy & 43 & 40.6 & 3 & 2.8 & 46 & 21.4 \\
\hline I don't know & - & - & 66 & 60.5 & 66 & 30.6 \\
\hline Total & 106 & 100 & 109 & 100 & 215 & 100 \\
\hline
\end{tabular}

Source: Fieldwork 2019

Climate change 100(47\%) was the main reason why participants in urban and rural areas choice particular cooking energy because of its consequences such as flooding, heat, diseases. This was followed by government policy 46(21.4) on the alternative choice of energy, including Bio-fuel, solar, and electricity. In the rural area, $66(60.5 \%)$ of women participants disinclined to comment on the reasons why they selected a particular set of cooking energy. Government policy 43(40.6) on alternative choices of cooking energy was well pronounced among the urban women while rural women explained little knowledge of the reason for the choice of a particular cooking method.

\section{Hypothesis 1}

$\mathrm{H}_{1}$ : There is a significant relationship between climate change and the choice of cooking energy by urban and rural women

$\mathrm{H}_{0}$ : There is no significant relationship between climate change and the choice of cooking energy among rural and urban women.

$\chi^{2}=87.40$

d.f $=3$

p-value $(0.000)<0.005$

Chi-square test was positive; therefore, $\mathrm{H}_{1}$ is accepted, since $\mathrm{x} 2=87.40$ with $\mathrm{p}$-value less than 0.005 . The percentage value of urban women participants $63(59.4 \%)$ that responded that the effects of climate change influence their choice of alternative cooking energy. Also, 40 (36.7\%) rural women that participated in this study said that the effects of climate change influence their acceptance of alternative choice of cooking energy.

\section{Hypothesis 2}

$\mathrm{H}_{1}$ : There is a strong relationship between government policy and climate change mitigation among rural and urban women.

$\mathrm{H}_{0}$ : There is no strong relationship between government policy and climate change mitigation among rural and urban women

$\chi^{2}=65.89$

d.f $=1$

p-value $=0.000<0.05$

$\mathrm{H}_{1}$ is accepted, since $\mathrm{x} 2=65.89$ with p-value less than 0.05 . The result of the chi-square test shows that there is a strong relationship between government policy and climate mitigation between rural and urban women in this study. The cross-tabulation shows a strong relationship between government policy and selection of the alternative source of cooking energy by urban women 43 (40.6\%) such as the provision of renewable energy for cooking (biofuel, electric cookers and solar energy). Government policy on climate change seems not extended to rural women, just $3(2.8 \%)$ of rural women participants said that their choice of alternative cooking energy was influenced by government policy

\section{Discussion, conclusion and policy implications}

Climate change is anthropogenic in most circumstances. From the submissions of various scholars, carbon emission from the use of fossil fuel, such as oil and wood, has been attributed to climate change. Many households in Nigeria depend on wood, gas, kerosene stove, solar energy, electric stove and other sources of energy for cooking. Most of these traditional sources of cooking energy used by the majority of Nigerians are climate-damaging. The cooking energy used by women is mostly determined by the availability of alternatives sources of energy. While the provision of alternative sources of cooking energy appears limited to urban women, rural women depend solely on wood for cooking. The paper, therefore, examined the determinants of the source of cooking energy for both rural and urban women. The paper also examined the relationship between climate change mitigation and available women's sources of cooking energy. The study used Rational Choice Theory to explain how individual decisionmakers can interact to generate often surprising aggregate outcome among women in urban and rural areas on the choice of cooking energy. The idea is hinged around the cumulative effects of the choices that individual women make and the human-induced degradation resulting from the choices. Scott's (2000) rational choice standpoint that all action is fundamentally 'rational' in character and that people calculate the likely costs and benefits of any action 
before deciding what to do drove the methods for formulating the research design. In a balanced combination of urban and rural targets, the study was carried out in Southwest, Nigeria: Ikeja, Akure, and Ile-Ife on the one hand and Ito-Ikin, Awo, and Yekemi on the other hand. Quantitative method of data collection was used to administer questionnaires among two hundred and fifteen women: Rural (110), and Urban (105). The paper found that women generally prefer the cheapest source of energy for cooking. The paper also discovered the presence of disproportionate differentials in government policies on climate change, which focused mainly on urban dwellers than rural dwellers. For instance, government subsidised urban women sources of cooking energy while rural women were more often self-reliance than not.

Furthermore, the availability of information and education on the effects of climate change were provided as reasons for the change in the sources of cooking energy among urban women. In contrast, rural women lack such crucial information and education on the effects of climate change such as flooding, heat, and diseases. The study concluded that climate change could be mitigated if the supports on the alternative sources of cooking energy were fairly distributed between rural and urban women in Nigeria.

This study examines sources of cooking energy for both rural and urban women in Southwest Nigeria. The focus of the study is majorly on climate change and how women in the urban and rural area of the Southwestmitigating climate change. This study utilised Rational Choice Theory to explain alternative choices of cooking energy available to women in Southwest instead of climate change prone cooking energy. Rational Choice is an economic theory but suitable for micro-macro explanations of human rationality in sociological and psychological sciences. The study focused on women because cooking has been ascribed as women role in Southwest because of patriarchy culture that has ingrained in the social patterns in the region, as noted above. The empirical reasons associated with the choice of urban and rural areas had to do with a need to understand government policies as related to climate change in both areas. The selection of rural area is also crucial in this study to measure climate change awareness and know if rural women had the benefits of the alternative choice of cooking energy as propagated by the government.

This study found high awareness of climate change among urban and rural women, as shown in Table 2 above. Majority of the participants said "yes" to the question on awareness of climate change. The responses of this form set tone for climate change acknowledgement rather than a denial that characterised climate change narratives by some highly-placed officials of Western countries in recent times. The acknowledgement of climate change sets footing for the next question, which seeks to know the causes of climate change in the Southwest, Nigeria. The participants mentioned deforestation, oil exploration and exploitation and carbon emission. It is important to note that deforestation and oil exploration and exploitation led the chat 73(34\%) and 68(31.6\%) respectively. The over dependency of rural women on woods for cooking could provide a challenging explanation of why deforestation topped the reasons for climate change. Many multinational oil companies in the region involved in activities that are related to climate change such as gas flaring.

The participants explained the effect of climate change on the inhabitants of the Southwest Nigeria to include heating, inundated rainfalls, diseases, desertification, drought, low agricultural yields and inability to plan for the season. The later factor hinges on the unpredictability of weather as a result of climate change. The participants explained the effects of climate change in terms of the spread of diseases $38(17.7 \%)$ and drought $36(16.7 \%)$. The participants' responses strengthen the deduction that the outbreak of communicable and non-communicable diseases such as Ebola and Lassa fevers are occasioned by climate change. The effects of climate change on the inhabitants of southwest enriched the researchers understanding of the need for alternative sources of cooking energy by both rural and urban women. Apart from fossil fuel and woods that have become traditional methods of cooking energy among women in the Southwest region; this study found the following alternative sources of cooking energy: bio-fuel, electricity, and solar. It should be noted that urban women had access to most of the alternatives to fossil fuels and woods. Urban women have government support towards the provision of an alternative to fossil fuels and woods. Urban women used bio-fuel 40(37.7\%), electricity 23(21.7\%) and solar 43(40.6\%). Many of rural women said "I don't know" because they lack access to an alternative source of energy for cooking $97(99 \%)$.

It should be noted that just $12(11.3 \%)$ of rural women participated in this study has access to electricity. The paper found that women generally prefer the cheapest source of energy for cooking. The study also discovered a disproportionate differential in government policies on climate change, which focused mainly on urban dwellers than rural dwellers. The lopsided nature of the policy direction denies rural women the crucial benefit of the availability of alternative cooking energy mobilised by government policy. For instance, government subsidised urban women sources of cooking energy while rural women were more often self-reliance than not. Furthermore, the availability of information and education on the effects of climate change were provided as reasons for the change in the sources of cooking energy among urban women. In contrast, rural women lack such crucial information and education on the effects of climate change such as flooding, heat, and diseases.

The submissions in this study presuppose that the effect of climate change on inhabitants of Southwest, Nigeria encouraged the urban and rural women focussed in this study to embrace an alternative to fossil fuel and 
woods if government avails the provision. Furthermore, a significant result, which supports Ajayi and Ajayi (2013) and Bisu, Kuhe and Loftyer (2016) respectively, is that policy enunciation for renewable energy is still far-fetched and, consequently, the primary source of cooking energy in Nigeria is the non-renewable energy such as fossil fuels and wood. Also paramount among these is that the transition to clean energy is neither "a piece of cake" nor "a pie in the sky" as Zimm, Goldemberg, Nakicenovic and Busch (2019) argued. As pointed out in Nevzorova and Kutchrov (2019), the need for break-away from the institutional and political barriers against the provision of clean energy in the developing world is not insurmountable. The study also found worthy similarity with the position of van dev Berg, Hof, Akenji, Edelenbosch, van Sluisveld, Timmer and van Vuuren (2019) on the need to the crucial need and importance of the transition from non-renewable energy lifestyle. Scott (2000) claims that Rational choice theories hold that individuals must anticipate the outcomes of alternative courses of action and calculate that which will be best for them. Rational individuals choose the alternative that is likely to give them the highest satisfaction (Carling, 1992). The conclusion that government policy, with the cooperation of citizens, can ameliorate the effects of climate change, also emerged from the study. Pro-poor energy access that will expand electricity access to rural areas could provide alternative cooking energy in both urban and rural areas. The method would scale up low carbon electricity services and cooking energy. Mahfoudh and Amar (2015) argued that access to clean energy remains "the most crucial service for improving the welfare of poor individuals". In other words, the finding aligns with a significant submission in this study, which states that pro-poor energy access has the quantity and quality of energy services that are accessible, affordable and sustainable, and it also empowers both men and women, especially the poor. The study also brought out the question of the continued vulnerability of women while using non-renewable energy sources as replicated in Akinsemolu and Olukoya (2020). In line with Megbowon, Mukarumbwa, Ojo and Olalekan (2018), the vulnerability may shape the country's malaria indicators. Nevertheless, the evaluation of the ancillary costs as suggested by Gillich, Brodecki and Hufendiek (2019), other than climate change mitigation, for embarking on the massive use of renewable energy could not be captured in this study. Finally, this study aligned with Dias, Simões Gouveia and Seixas (2019) and Rahut, Ali, Mottaleb and Aryal (2019) that capacity for household affordability and education matter in cooking energy choices and policy.

The study, therefore, concluded that climate change could be mitigated if the quantum of supports for the alternative sources of cooking energy were evenly attended to between rural and urban women in Nigeria. The government should invest heavily on green energy in the rural area as well as urban area.

\section{References}

Aina, I. O. (1998). Women, culture and society. In A. Sesay \& A. Odebiyi (Eds.), Nigerian women in society and development (pp. 3-33). Ibadan, Nigeria: Dokun Publishing.

Amar, M. B. (2012). Energy consumption and economic growth: the case of African Countries. The Journal of Energy and Development, 38(1 \& 2), 65-78.

Berge, E. \& Stenseth, N. C. (1998). Law and the governance of renewable resources: studies from Northern Europe and Africa. Oakland, California: ICS Press.

Carling, A. (1992). Social Divisions. London, UK: Verso.

De Young, R. (1999). Tragedy of the commons. In D. E. Alexander \& R. W. Fairbridge (Eds.), Encyclopedia of Environmental Science (pp. 601-602). Hingham, MA: Kluwer Academic Publishers.

Dogo, S. A. (2014). The Nigerian patriarchy: when and how? Cultural and Religious Studies, 2(5), 263-275. Doi: $10.17265 / 2328-2177 / 2014.05 .002$.

Emodi, N. V. \& Boo, K. (2015). Sustainable energy development in Nigeria: overcoming energy poverty. International Journal of Energy Economics and Policy, 5(2), Pp. 580-5971.

Folami, O. \& Olaiya, T. A. (2016). Gender, storytelling and peace construction in a divided society: a case study of the Ife/Modakeke conflict. Cogent Social Sciences, 2(1), 1-19. DOI: 10.1080/23311886.2016.1159015

Fuchs, D. A. (2013). An institutional basis for environmental stewardship: the structure and quality of property rights. Dordrecht/Boston/London: Kluwer Academic Publishers.

Hardin, G. (1968). The tragedy of the commons. New Series, 162(3859), 1243-1248.

Heath, G., Warner, E., Steinberg, D. \& Brandt, A. (2015). Estimating U.S. Methane emissions from the natural gas supply chain: approaches, uncertainties, current estimates, and future studies. A Technical Report No. NREL/TP-6A50-62820 for Joint Institute for Strategic Energy Analysis (JISEA) and Stanford University. Accessed online 02/01/17 from http://www.nrel.gov/docs/fy16osti/62820.pdf

Homans, G. (1961). Social behaviour: its elementary forms. London, UK: Routledge and Kegan Paul.

Igbelina-Igbokwe, N. (May 30, 2013). Contextualizing gender-based violence within patriarchy in Nigeria. Pambazuka News: Voices for Freedom and Justice. Accessed online 01/01/17 from http://www.pambazuka.org/gender-minorities/contextualizing-gender-based-violence-within-patriarchynigeria

Latta, P. A. (1968). The tragedy of the commons" by Garrett Hardin. In introduction to sustainable development, Encyclopedia of Life Support Systems (EOLSS) https://www.eolss.net/Sample-Chapters/C13/E1-45-01- 
07.pdf

Makama, G. O. (2013). Patriarchy and gender inequality in Nigeria: the way forward. European Scientific Journal, 9(17), 115-144.

Malinowski, B. (1922). Argonauts of the Western Pacific. London, UK: Routledge and Kegan Paul.

Mauss, M. (1925). The gift. London: Routledge and Kegan Paul.

Olaiya, T. A. (2011). Tax administration and burden of governance in Nigeria and Ghana: a comparative analysis. Germany: Lap Lambert Academic Publishing.

Olaiya, T. A. (2013). Youths and ethnic movements and their impacts on party politics in ECOWAS member states. Sage Open, 4(1), 1-12.

Olaiya, T. A. (2014). Examining the Colonial Basis of Anomie in African Youth. Ife Social Sciences Review, Vol. 24, No. 1, pp. 152-171

Olaiya, T. A. (2016). Examining the Political-Economy of Cocoa Exports in Nigeria. International Journal of Applied Economics and Finance. Vol. DOI: 10.3923/ijaef.2016, http://scialert.net/qredirect.php?doi=ijaef.0000.76708.76708\&linkid=pdf

Olaiya, T. A. (2016b). Proto-nationalisms as sub-text for crisis of governance in Nigeria. Sage Open, DOI: http://dx.doi.org/10.1177/2158244016643139

Olaiya, T. A., Ayinde, O. J., Alayinde, O. Z., \& Akinwole, O. T. (2016). Sustainable economy: agricultural development policies and anthropogenic factors in Tropical Africa. Ife Social Science Review. 12, 464-476.

Olomola, P.A. and A.V. Adejumo, 2006. Oil price shock and macroeconomic activities in Nigeria. Int. Res. J. Fin. Econ., 3: 28-34.

Oluyole, K.A. \& R.A. Sanusi, (2009). Socio-economic variables and cocoa production in Cross River State, Nigeria. Journal of Human Ecology, 25, 5-8.

Ostrom, E. (1990). Governing the commons: the evolution of institutions for collective action. New York: Cambridge University Press.

Ostrom, E. (1998). A behavioural approach to the rational choice theory of collective action: presidential address. American Political Science Association, 1997. American Political Science Review, 92(1), 1095-1111.

Oyedepo, S. O. (2013). Energy in perspective of sustainable development in Nigeria. Sustainable Energy, 1(2), $14-25$

Pachauri, S., Rao, N. D., Nagai, Y. \& Riahi, K. (2012). Access to modern energy assessment and outlook for developing and emerging regions. A joint publication prepared by the IIASA Energy Program and the UNIDO Energy and Climate Change Branch on the project Global Energy Assessment: Developing Policy Tools for Jointly Reducing Energy Poverty and Greenhouse Gas Emissions.

Parsons, T. (1937). The structure of social action. New York: McGraw-Hill.

Premium Times, (March 12, 2013". Firewood smoke is the third largest killer of women, children in NigeriaWHO. An online news magazine. Accessed 01/01/17 from http://www.premiumtimesng.com/news/124320firewood-smoke-is-third-largest-killer-of-women-children-in-nigeria-who.html.

Sachs, J. D. (2015). The age of sustainable development. New York: Columbia University Press.

Scott John (2000). Rational Choice Theory. In G. Browning, A. Halcli, \& F. Webster (Eds.), Understanding contemporary society: theories of the present (126-138). Thousand Oaks: Sage Publications.

Shiva, V. (1993). Monocultures of the mind: understanding the threats to biological and cultural diversity. University of Guelph: Inaugural Hopper Lecture, 21 September 1993.

The Nation (August 31, 2014). 93,000 Nigerians die annually from firewood smoke- ICEED. Accessed online 01/01/17 from http://thenationonlineng.net/93000-nigerians-die-annually-from-firewood-smoke-iceed/

United State Environmental Protection Agency (US EPA), (2016). Overview of greenhouse gasses. Accessed 02/01/17 from https://www.epa.gov/ghgemissions/overview-greenhouse-gases

Vallero, D. A. (2006). Paradigms lost: learning from environmental mistakes, mishaps, and misdeeds. Burlington, USA and Oxford, UK: Butterworth Heinemann Elsevier.

Villalobos, V. M. (1989). Advances in tissue culture methods applied to coffee and cocoa plant biotechnology for developing countries. London, UK: CTA/FAO Chayce Publication Services.

Weber, M. (1920). Conceptual exposition. In M. Weber, G. Roth \& C. Wittich Economy and Society (Eds.), Berkeley: University of California Press.

Samadiafshar, A. \& Ghorbani, A. (2018). Clean energy management. In S. Gokten, \& G. Kucukkocaoglu (Eds.), Energy Management for Sustainable Development (85-97). London, UK: IntechOpen Limited.

Situmbeko, S. M. (2018). Towards a sustainable energy future for sus-Saharan Africa. In S. Gokten, S. \& G. Kucukkocaoglu (Eds.), Energy Management for Sustainable Development (47-68). London, UK: IntechOpen Limited.

Edomah, N. (2018). Historical drivers of energy infrastructure change in Nigeria (1800-2015). In S. Gokten \& G. Kucukkocaoglu (Eds.), Energy Management for Sustainable Development (24-44). London, UK: IntechOpen Limited. 
Megbowon, E., Mukarumbwa, P., Ojo, S. \& Olalekan, O. S. (2018). Household cooking energy situation in Nigeria: insight from Nigeria malaria indicator survey 2015. International Journal of Energy Economics and Policy, $8(6), 284-291$.

Arowolo, W., Blechinger, P., Caderb, C. \& Perez, Y. (2019). Seeking workable solutions to the electrification challenge in Nigeria: Minigrid, reverse auctions and institutional adaptation. Energy Strategy Reviews, 23, 114-141.

Sa'ad, S. \& Bugaje, I. M. (2016). Biomass consumption in Nigeria: trends and policy issues. Journal of Agriculture and Sustainability, 9(2), 127-157.

Federal Republic Of Nigeria (2016). Sustainable energy for all action agenda (SE4ALL-AA). A Report of InterMinisterial Committee On Renewable Energy And Energy Efficiency (ICREEE).

Gujba, H., Mulugetta, Y. \& Azapagic, A. (2015). The household cooking sector in Nigeria: environmental and economic sustainability assessment. Resources, 4, 412-433.

Akinsemolu' A. A. \& Olukoya' O A. P. (2020). The vulnerability of women to climate change in coastal regions of Nigeria: a case of the Ilaje community in Ondo State. Journal of Cleaner Production, 246, https://doi.org/10.1016/j.jclepro.2019.119015.

Edomah, N. (2019). Governing sustainable industrial energy use: Energy transitions in Nigeria's manufacturing sector. Journal of Cleaner Production, 210, 620-629.

Federal Republic Of Nigeria (2003). National energy policy. A report of The Presidency: Energy Commission of Nigeria.

Ajayi, O. O. \& Ajayi, O. O. (2013). Nigeria's energy policy: inferences, analysis and legal ethics toward RE development. Energy Policy, 60, 61-67.

Bisu, D. Y., Kuhe, A., Iortyer, H. A. (2016). Urban household cooking energy choice: an example of Bauchi metropolis, Nigeria. Energy, Sustainability and Society, 6(15), 1-12.

Rahut' D. B., Ali' A., Mottaleb' K. A. \& Aryal, J. P. (2019). Wealth, education and cooking-fuel choices among rural households in Pakistan. Energy Strategy Reviews, 24, 236-243.

Dias, L. P., Simões, S., Gouveia, J. P. \& Seixas, J. (2019). City energy modelling- Optimising local low carbon transitions with household budget constraints. Energy Strategy Reviews, 26, https://doi.org/10.1016/j.esr.2019.100387.

Zimm, C., Goldemberg, J. Nakicenovic, N. \& Busch, S. (2019). Is the renewables transformation a piece of cake or a pie in the sky? Energy Strategy Reviews, 26, https://doi.org/10.1016/j.esr.2019.100401.

Nevzorova, T. \& Kutcherov, V. (2019). Barriers to the wider implementation of biogas as a source of energy: A state-of-the-art review. Energy Strategy Reviews, 26, https://doi.org/10.1016/j.esr.2019.100414.

Gillich, A., Brodecki, L. \& Hufendiek, K. (2019). Impacts of complementing goals besides emission targets on $\mathrm{CO} 2$ mitigation cost: A model-based analysis. Energy Strategy Reviews, 26, https://doi.org/10.1016/j.esr.2019.100395.

Nicole J. van den Berg, N. J., Hof, A. F., Akenji, L., Edelenbosch, O. Y., van Sluisveld, M. A E., Timmer, V. J. \& van Vuuren, D. P. (2019). Improved modelling of lifestyle changes in Integrated Assessment Models: Cross-disciplinary insights from methodologies and theories. Energy Strategy Reviews, 26, https://doi.org/10.1016/j.esr.2019.100420.

Griffiths, S. (2019). Energy diplomacy in a time of energy transition. Energy Strategy Reviews, 26, https://doi.org/10.1016/j.esr.2019.100386.

Gielen, D., Boshella, F., Saygin, D., Bazilian, M. D., Wagner, N. \& Gorini, R. (2019). The role of renewable energy in the global energy transformation. Energy Strategy Reviews, 24, 38-50.

Awodumi, O. B. \& Adewuyi, A. O. (2020). The role of non-renewable energy consumption in economic growth and carbon emission: Evidence from oil-producing economies in Africa. Energy Strategy Reviews, 27, https://doi.org/10.1016/j.esr.2019.100434

Ejiogu, A. R. (2013). A nuclear Nigeria: How feasible is it? Energy Strategy Reviews, 1(4), 261-265.

Sa'ad, S. \& Isah, S. I. (2016). Empirical analysis of transportation demand for oil products in Nigeria: Using error correction approach. Energy Strategy Reviews, 10, 53-61.

Mahfoudh, S. \& Amar, M. (2014). The importance of electricity consumption in economic growth: the example of African nations. The Journal of Energy and Development, 40(1/2), 99-110.

Shankar, U. \& Sharma, S. (2012). Access to energy: looking through the prism of human rights — the Indian experience. The Journal of Energy and Development, 38(1/2), 221-239. 